\title{
UMA LEITURA ANTROPOLÓGICA DO MUNDO MODERNO
}

\author{
LÉVI-STRAUSS, Claude. \\ A antropologia diante dos \\ problemas do mundo moderno. \\ São Paulo: Companhia das Letras, 2012. 94 p. \\ POR \\ Joicy Suely Galvão da Costa Fernandes ${ }^{l}$ \\ Ozaias Antonio Batista
}

\begin{abstract}
A antropologia diante dos problemas do mundo moderno é um livro que A congrega três conferências proferidas pelo antropólogo Claude Lévi-Strauss

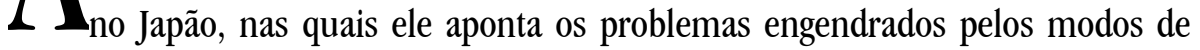
vida das civilizações ocidentais modernas, mostrando como a antropologia auxilia a pensar tais problemáticas por meio das experiências de pesquisa de campo em realidades sociais comumente nomeadas como "primitivas".

Em sua primeira conferência, "O fim da supremacia cultural do Ocidente", 0 autor afirma que as civilizações ocidentais, ao longo de seu processo de desenvolvimento, se colocaram em um patamar de superioridade diante de outras
\end{abstract}

\footnotetext{
${ }^{1}$ Professora de Sociologia do Instituto Federal do Rio Grande do Norte (IFRN). Doutoranda do Programa de Pós-graduação em Ciências Sociais (PPGCS/UFRN). Mestre em Ciências Sociais (PPGCS/UFRN). Graduada em Ciências Sociais (UFRN). Contato: joicy.fernandes@ifrn.edu.br ${ }^{2}$ Professor substituto do Departamento de Fundamentos e Políticas da Educação (DFPE//UFRN). Doutorando do Programa de Pós-graduação em Ciências Sociais (PPGCS/UFRN). Mestre em Ciências Sociais (PPGCS/UFRN). Graduado em Ciências Sociais (UFRN). Contato: ozaias_antonio@hotmail.com
} 
civilizações, em decorrência do progresso tecnológico e científico alcançados. Esse avanço trouxe benesses, mas também acarretou em um aumento no poder destrutivo do próprio homem, do espaço e dos recursos naturais.

Com isso, Lévi-Strauss expressa que um dos maiores ensinamentos que a antropologia pode deixar ao homem ocidental é a humildade, pois essas sociedades "primitivas" apresentam lições dignas de atenção, tendo em vista que elas sabem estabelecer certo equilíbrio entre as necessidades humanas e a preservação dos recursos naturais.

Nesta conferência o autor afirma que as distintas realidades sociais servem enquanto constatação da diversidade cultural existente, entendendo que

\begin{abstract}
[...] a atenção e o respeito demonstrado pelo antropólogo às diferenças entre as culturas como àquelas próprias a cada uma constituem 0 essencial de seu procedimento. Assim, o antropólogo não procura elaborar uma lista de receitas em que cada sociedade irá se servir segundo seu estado de espírito toda vez que perceber em seu seio uma imperfeição ou uma lacuna. As fórmulas próprias a cada sociedade não são transponíveis a nenhuma outra (LÉVI-STRAUSS, 2012, p. 37).
\end{abstract}

Desse modo, o antropólogo deve priorizar a diversidade cultural a fim de garantir um optimum de diversidade, que surge mediante as particularidades inerentes à realidade social estudada.

Em "Três grandes problemas contemporâneos: a sexualidade, 0 desenvolvimento econômico e o pensamento mítico", título da segunda conferência, Lévi-Strauss apresenta como as sociedades ocidentais se portam frente aos problemas inerentes às esferas familiar, econômica e religiosa, mantendo enquanto quadro comparativo as realidades sociais "primitivas".

A procriação assistida é um fenômeno cada vez mais recorrente na contemporaneidade. Entretanto, tal realidade trouxe consigo implicações morais, psicológicas e sociais para o cotidiano dos indivíduos, uma vez que o parentesco constituído pelo homem ocidental é comumente associado com laços de sanguinidade na qual os vínculos sociais na constituição da lógica parental não imperam.

Esse processo de procriação assistida implica na dissociação da relação sexualidade-procriação; no surgimento da possibilidade dos indivíduos procriarem "sozinhos", na medida em que eles assumem a parentalidade sem a presença de 
qualquer parceiro reconhecido; no trato das informações referentes à origem étnica da criança, podendo ser ou não fornecidas pelos pais; e no embate religioso em torno do ato da procriação. Todos esses elementos servem como subsídios para a criação de um tratado de bioética.

Em contrapartida, tais dilemas inexistem em sociedades "primitivas", na medida em que os sujeitos acionam outros mecanismos, que não jurídicopsicológicos ou biológicos, para a constituição do casamento e da procriação, podendo existir o envolvimento de diversos parceiros e parceiras, como no caso dos índios Tupi-Kawahib, estudados por Lévi-Strauss durante seu trabalho de campo no Brasil, em 1938. Dessa forma, o embaraço engendrado no processo de fertilização in vitro e a obtenção da parentalidade socialmente reconhecida não se encontram nessas realidades sociais.

Todavia, o autor reitera que o papel da pesquisa antropológica não é fazer com que as populações adotem os costumes umas das outras, mas sim viabilizar 0 processo de desnaturalização de costumes e princípios, sendo estes compreendidos enquanto fenômenos culturalmente constituídos.

Com relação à lógica que rege a economia das sociedades "primitivas", Lévi-Strauss argumenta que elas adotam outros padrões de produtividade que visam o bem-estar grupal, assim como o equilíbrio possível entre os recursos naturais e a necessidade coletiva. A partir daí, tem-se um modelo que resiste ao processo industrial capitalista, diferindo do adotado pela maioria das sociedades ocidentais.

Lévi-Strauss encerra essa segunda conferência argumentando em favor da aproximação entre os pensamentos científico e mítico, vislumbrando mais semelhanças do que diferenças em seus processos de elaboração. Mesmo sabendo que a ciência opera por bases racionalistas e o mito aciona elementos do mundo sensível, a narrativa histórica, entendida como recurso utilizado pelo homem moderno para explicar a si, o outro e o mundo, não pode ser considerada como construção propriamente objetiva, sabendo que em sua composição existem, à semelhança das narrativas míticas, elementos construídos a partir da cosmovisão do narrador.

Por consequência, vários estudos etnológicos mostram a existência de múltiplas narrativas míticas e históricas, tanto em sociedades com ou sem escrita. Tal constatação, argumenta Lévi-Strauss, serve para minimizar a distância imposta entre essas narrativas. Assim, a explicação dada pelo homem ocidental para os 
fenômenos apreendidos não é mais ou menos válida em comparação com a elaborada pelos povos "primitivos".

Durante todo o livro Lévi-Strauss fala de sua admiração pela cultura japonesa, sendo esse o leitmotiv de sua última conferência: "Reconhecimento da diversidade cultural: 0 que nos ensina a civilização japonesa". Tamanha admiração se deu em decorrência do Japão se abrir ao desenvolvimento tecnológico e econômico, sem negligenciar aspectos singulares de sua constituição enquanto nação. Isto significa dizer que o país não se entregou totalmente aos padrões de desenvolvimento oriundos do Ocidente, mantendo certa originalidade cultural manifesta nas artes, vestimenta, alimentação. Essa não foi uma postura recorrente, porque algumas civilizações se abriram totalmente à invasão ocidental e outras assumiram uma posição hermética, adquirindo 0 título de subdesenvolvidas por não se ocidentalizarem-se.

A discrepância sociocultural existente nas várias civilizações foi explicada por muito tempo através de pressupostos evolucionistas que tendiam a simplificar a diversidade cultural. Porém, por meio de pesquisas no campo da genética e do crescimento de estudos etnográficos, confirmaram-se as aferições antropológicas que observavam as variações nos índices de desenvolvimento social e tecnológico enquanto particularidades condicionadas pela constituição cultural, e não oriundas das características biológicas do agrupamento humano.

Daí, a importância da interlocução entre os saberes da biologia e da antropologia serviu, neste caso, para desmistificar a tese que aproximava as diferenças culturais e as estruturas biológicas encontradas nos seres humanos. Diante disso, ficou viável caracterizar as experiências sociais e culturais como catalisadoras do desenvolvimento histórico de cada civilização, excluindo a abordagem evolucionista das pesquisas antropológicas. Entendendo com isso que as construções sociais são fruto das singularidades culturais de cada população, estando essas particularidades a condicionar o desenvolvimento biológico de seus nativos, uma vez que 0 casamento, amamentação, alimentação, são instâncias que independem da estrutura biológica dos sujeitos.

Além da leitura que Lévi-Strauss faz acerca do mundo moderno, passear pelas páginas que compõem o presente livro instiga pesquisadores a pensarem sobre a importância da antropologia enquanto disciplina que auxilia no exercício da alteridade, em uma realidade que se mostra cada vez mais plural. 


\section{REFERÊNCIA}

LÉVI-STRAUSS, Claude. A antropologia diante dos problemas do mundo moderno. São Paulo: Companhia das Letras, 2012.94 p. 